\title{
Patronage and Capitalism in the Musical Associations of Late Nineteenth-Century Colonial Manila
}

\author{
Arwin Q. Tan \\ University of the Philippines College of Music, Philippines \\ e-mail: aqtan@up.edu.ph \\ DOI: https://doi.org/10.37134/mjm.vol8.8.2019
}

Published online: 18 December 2019

Cite this article (APA): Tan, A. Q. (2019). Patronage and Capitalism in the Musical Associations of Late NineteenthCentury Colonial Manila. Malaysian Journal of Music, 8, 122-135. https://doi.org/10.37134/mjm.vol8.8.2019

\begin{abstract}
The rapid economic growth in the colony beginning in the mid-nineteenth century gave rise to a modernity that transformed the musical mode of production in Manila. A new market comprised of the culturally-supportive elite and middle-class population patronised musical productions. In addition, musicians and other artists formed unions to create an institutionalised representation of themselves corresponding to the larger socio-political and economic forces in the network of production, creating new relations necessary in the existing social formation. Exchanges between the various players of the musical mode of production required matching forces to avoid exploitation, particularly of labour. This article examines three of the more prominent musical associations in the late nineteenth century-Liceo Artístico-Literario, Sociedad de Conciertos Unión Artístico-Musical, and Sociedad Musical Filipina de Santa Cecilia-investigating how they advanced music and education and promoted the arts, regulated the practice of music making, responded to the market demand for commoditised music labour, and accelerated modernity in Philippine music during the last decades of Spanish colonial rule. Their patronage represented the continuing feudal and new capitalist systems of managing musical productions and remunerating musical labour, providing a possibility for indigena (island-born native) musicians to accumulate cultural capital and afford them social mobility in the colonial system. Membership in these associations became symbols of prestige, which helped establish social networks among Filipino musicians.
\end{abstract}

Keywords: alternative modernity, capitalism, musical association, patronage

\section{Musical Mode of Production in Manila in the Late Nineteenth Century}

In the late nineteenth century, the Philippines experienced a new political economy dictated by capitalism, which resulted from the liberalisation of trade with foreign countries other than Spain. The opening of trade with companies from Britain, Germany, France, and the United States of America began in the early nineteenth century after the Manila Galleon seized its trans-Pacific operations in 1815. The new business and trading regulations benefited the colonial population, primarily the insulares (criollos or Spaniards born in the Islands), Spanish mestizos, and Chinese mestizos. They became active agricultural producers and exporters and, in the process, many were able to climb the colonial socio-economic ladder and became the middle class of the nineteenth century. The most remarkable symbol of this elevated social position was the provision for higher education for their sons, who would later comprise the nascent ilustrado (enlightened) class. The ilustrados's liberal and scientific education would eventually create an alternative modernity in the colony, particularly the beginnings of the idea of a Filipino nation (Mojares, 2006, pp. 451-466). This education also paved the way for 
the appreciation and support of Western music played by Filipinos and Europeans in the late nineteenth century as a result of the faster flow of people and goods between the colony and Europe (Maceda, 1973, p. 223).

Modernity as used in this paper pertains to the notion of emergent progressive practices, marked by secularism and liberalism, ushered by the future-oriented ilustrados. It is constitutive of cultural changes emanating 'from below', which are manifested, in real material practices that involved complex cross-cultural negotiations resulting from the Filipinos' entanglements with Spanish hegemony and the unprecedented effects of globalisation in the late nineteenth century. These include the emergent imperial capitalist market that marshalled rapid urbanisation in the colony. It also accelerated the transmission of modern technology, images, books, and even the new social order of international politics (Buenconsejo, 2017, p. xiv). Thus, a kind of alternative modernity that became apparent in the late nineteenth century Philippines involved cultural and economic changes that centred on a consciousness which advanced the idea of individualism and the right to govern one's self- a bourgeoning idea that would climax in the revolution of 1896 . $^{1}$

These alternative modernities are manifested in the vibrant cultural milieu of the capital such as the formation of musical associations that practiced a utopian kind of capitalism. Other manifestations of the presence of alternative modernities include the participation of female musicians in cultural productions as entrepreneurs; and the printing of transcultural music for domestic consumption (Tan, 2018, p. v). Naturally, the ilustrados, together with the emerging middle class, became the key players in this new political economy of late nineteenth century Philippines. They established intertwining social relations as they participated in the mode of production of culture, with strong eagerness for social and cultural advancement that contributed to the development of a modern Filipino cultural imagination.

Capitalism caused the emergence of this critical period of modernity in nineteenth century Manila as it encouraged a culture dominated by consumption, introduced new forms of exchanges - particularly of moneyand transformed the mode of production of music in the public sphere. This study examines the relation of music and capitalism in Manila, focusing on the rise of musical associations whose patronage for musical productions activated changes in social relationships that altered music making in the colony with new material and social practices. Patronage from the musical associations created strategies for more opportunities and social representation of Filipino musicians and it encouraged the institutionalisation of music academies and performing groups. It also recognised and reinforced the economic valuation of musicians' labour and stimulated the increased commodification of music materials. A central institution of the modern capitalist system was the market which was made up of a paying public, the incipient Filipino middle class who used their developed taste for Western music as a marker for their elevated social status and the reproduction of their newly acquired cultural capital (Bourdieu, 1986, p. 16).

Focusing on the proliferation of musical associations, this study interrogates the workings of a new but fragile patronage system that fostered globalisation and modernity, and how they facilitated new ways of defining the emergent consciousness of Filipino-ness at the turn of the twentieth century. What new relations did the ilustrado, the colonial elite, and the burgeoning middle class public sphere engaged in as they involved themselves in the patronage of musical productions and the propagation of musical knowledge? How did these associations, and the bands and orchestras they patronised represent the new social order? How did they assist in the transformation of musical taste among those who consumed musical commodities and productions? How did it support the perpetration of the ideologies and representations in the interest of the capitalists?

\section{Manila's Three Prominent Musical Associations in the Late Nineteenth Century}

This study highlights three prominent musical associations in the late nineteenth century-Liceo Cientifico Artistico Literario, more commonly referred to as Liceo Artistico-Literario, founded in 1878 and dissolved in 1883; Sociedad de Conciertos Unión Artístico-Musical, founded in 1885; and Sociedad Musical Filipina de Santa Cecilia, founded in 1888. They represent three different categories of associations, which were formed through their founders' common interests, and were reflected in their primary objectives. One category preserves the ilustrados' aim of advancing literacy and culture, which lent associations their literary-musical nature. This kind of musical associations resonated to the ideals of early nineteenth century European musical societies which focused on their literary nature and published extensive biographies of Western composers and new music history books such as Forkel's biography of Bach (1802); Carpani's biography of Haydn (1812); 
Nissen's biography of Mozart (1828); Abraham Rees's General History of Music (1798) and Cyclopedia (1802) (Goehr, 1992, p.241). Membership was basically from the small Spanish population in the colonypeninsulares (Spaniards born in Spain) and insulares - and from the ilustrado class.

Liceo Cientifico Artistico Literario was one of the earliest associations founded in Manila that aimed to "protect the interests of the lovers of music, fine arts, [and] literature; and cultivate aesthetic taste" (Bañas, 1924, p. 17). Its membership was generally comprised of prominent composers, theatre artists, painters, sculptors, playwrights, dramatists, poets, and literary artists. It held veladas (salon literary-musical performances), symphonic concerts, dramatic theatre works, painting exhibits, conferences and lectures, and competitions for new artistic creations. It was through the Liceo's Certamen that José Rizal — the future national hero of the Philippines promoted by the American Insular Government in the early twentieth century-was accorded prestige through winning twice, elevating his status in the realm of literary creation. Although shortlived, the Liceo is recognised to have left a mark in the colony's cultural production through the numerous functions it held which emphasised the propagation of artistic education and the development of aesthetic taste among the colonial population.

The second category focused on the regulation of musical labour, which adhered to the professionalisation of musicians in the practice of their art. This was the musicians' answer to the growing commodification of their labour in Manila's new capitalist market. This kind of association is represented by the Sociedad de Conciertos Unión Artístico-Musical. Membership in this kind of association is primarily composed of practicing musicians. The Unión Artístico-Musical's primary intent was to form a system that would regulate the valuation of musicians' labour in order to optimise the advantage, which could be derived from the expanding middle class market of nineteenth century Manila. In addition, it aimed to improve the 'moral' and 'material' situation of the orchestra members through the holding of regular concerts and provide orchestral assistance to theatre productions and private gatherings requiring music performances. Its 100 members were meticulously chosen by a governing board - in the form of a competitive examination - which accorded a status distinction the carried prestige beside receiving monetary remuneration and taking part in the distribution of the association's revenues derived from engagements.

The third category, Sociedad Musical Filipina de Santa Cecilia exemplifies a kind of association that emphasised the intermediary functions of an association, which acts as the manager, marketing agent, source of new training, and provider of new music materials and instruments. Associations of this kind were composed of a mixture of members - e.g. businessmen, musicians, and artisans - whose commonality was rooted in their love for music and its propagation in the colonial society. This kind of association also reflected the entrepreneurial character of an institution whose juridical personality was mandated to reproduce capital, in the form of profits, to be used in improving the welfare of its members. This third kind also hints at an ideal version of capitalism in which the wealthy owners of the means of production reproduce economic capital with the intention to aid the poorer members of the association whose musical labour is the only means to reproduce such capital. Acting as a space for developing social capital through the network of relations developed among members, these associations provided musicians from the lower class a means to participate in the conversion of their accumulated cultural capital into economic capital (Bourdieu, 1986, p. 16).

The nature of the Sociedad Musical Filipina de Santa Cecilia adhered to a multi-class membership in which the officers, comprised mainly of aficionados belonging to the upper class, acted as agents for the improvement of the financial disposition of the majority of musician-members who belonged to the lower class. The organisational structure is divided into the 'general sections' and 'special permanent commissions.' The general sections were scientific, piano, singing, instrumental, and cooperation, to which the members were free to join according to their aptitudes and hobbies, while the special permanent committees were propaganda, artistic direction, technical direction, and external relations, and the membership in these committees were selected and appointed by the association's Board of Directors (p. 7). An important component of the Sociedad Musical Filipina de Santa Cecilia was the presence of an annexed women's section which was governed by a special board comprised of the lady-members, and which held exclusive literary-musical events only for them (p. 15).

Many of the musical associations were founded on similar precepts which can be generalised as: 1) development of music education; 2) promotion and improvement of the arts; 3) protection of the common interests of Filipino musicians and music teachers; 4) cultivation of aesthetic tastes among the supporters of 
arts; and 5) honouring a respected person, character, or saint (Bañas, 1924, pp. 17-20). The musical associations of Manila maintained their own resident orchestras and bands, whose inherent organisational structures accustomed their members to the considerations of social ordering. For example, the Sociedad de Conciertos Unión Artístico-Musical maintained a 100-member orchestra, as mandated by Article 51 of its regulations. This huge orchestra was from the conglomeration of the four small orchestras of its conductor-members: Pedro Gruet, Eulogio Revilla, Francisco Domingo, and Bruno Santa Maria. Similarly, the Sociedad Musical Filipina de Santa Cecilia also maintained its own orchestra like other associations, which were established at a later time. Examples include Circulo Musical de Pandacan which boasts of its all-Filipino opera troupe and its renowned Orkestang Babae, and the later Asociacion Musical de Filipinas which would eventually establish the Manila Symphony Orchestra in the 1930s.

\section{Social Ordering and Mobility}

The orchestra illustrates social ordering through its structure where a recognised master symbolises the essential figure of power. This figure is represented by the conductor who epitomises the image of the legitimate and rational organiser of a production. He symbolises economic power, which is capable of harmoniously setting the programme of history in motion as codified by the composer. Led by the conductor who maintains complete control over musical interpretation, the members of the orchestra and bands act as labouring musicians who are mere followers in achieving a perfect standard sound commanded by the leader (Attali, 1985, p. 66). The structure of these musical groups also represents power in the industrial economy in which the musicians are hierarchically ranked, occupying specific positions within the orchestra's organisation and are required to render their individual parts. Thus, in maintaining resident orchestras and bands, the musical associations were mirroring the social hierarchy that was imposed by the capitalist system, particularly in the production processes that accelerated the movements of transactions in the economy.

The following are Filipino musicians who served as music directors. Marcelo Adonay sat in the board of the Union Artistico Musical while serving as maestro de capilla of San Agustin Church, was a committee member of the Asociacion Musical de Filipinas, and occasionally conducted the San Juan del Monte Orchestra. Bonifacio Abdon was the earlier Asociacion Musical de Filipinas' music director upon its reorganisation in 1912, and was one of the founders of the Manila Chamber Music Society. He also conducted the Rizal Orchestra, and founded the Orchestra Oriental (Manuel, 1970, pp. 7-9). Bibiano Morales was a member of the Centro de Bellas Artes and the earlier Asociacion Musical (Bañas, 1924, p. 96). Ladislao Bonus was the director of Teatro de Pandacan and also directed the Orkestang Babae of Circulo Musical de Pandacan, the Banda Pasig, the Orquesta Marikina and the Banda Arevalo of Quiapo (p.116). Cayetano Jacobe conducted the Tiwi Orchestra, Banda Cuaderno, Banda Pagsanjan, and Banda Tipas (Manuel, 1970, p. 230); and Lorenzo Ilustre conducted the Rizal Orchestra of Batangas, Banda Ibaan, and an all-female rondalla group (Tan, 2007, p. 12).

Their mobility corroborates the typical involvement of a musician with numerous orchestras or bands, as opposed to the traditional restricted movement of members of the lower class in both feudal and capitalist systems (Murthy, 2015, p. 153). As the conductor of several music groups from diverse places, they served as links to the vast network of cultural space from which production relations were formed. They hint at these major locales belonging to the same network of musical productions, thus maintained a connected past.

\section{Relations and Forces of Musical Production in Manila}

Music's new mode of production paved the way for the entry of new players that expanded the relations of production, thanks to the introduction of modern technology that intensified the forces of production. The musical mode of production in nineteenth-century Manila was formed by the stable presence of a network of musicians, patrons, organisations, educators, impresarios, aficionados, and audiences who related to one another and comprised the characters of what Marx referred to as 'relations of production.' It refers to the "social allocation of production, that is, the relationships among those who produce (labour), those who control what it takes to create the product (means of production), and those who appropriate the product (surplus)" (Qureshi, 2002, p. 88). Manila's musical scene in the late nineteenth century provided a space where a complex web of 
relations developed among the producers, distributors, and consumers of cultural productions. Musicians such as José Estella, Bonifacio Abdon, and Ladislao Bonus maintained close working relationships with wealthy patrons such as Francisco Roxas and Bonifacio Arevalo, while establishing social networks with owners of stores selling musical products, printing presses, theatres/concert halls, and many others. The rise of the demand for theatrical and orchestral performances obligated musicians to organise themselves and forged relations with a new kind of patronage system — one that responded to the imperatives of capitalist economy.

Completing the concept of mode of production is the 'forces of production', which are primarily the technological basis for economic activity. They are conceived as "a combination of the means of productionthe technological/material base of production and reproduction of the social formation" (Olmsted, 2002, p. 108). Examples of forces of production are new tools, machineries, printing presses, newly constructed theatres, and musical instruments. In her study of music circulation in nineteenth century Manila, Chua (2018) mentions that many peninsulares migrated to the capital and established publishing companies that printed and distributed music sheets and other commodities in the thriving business street of Escolta. Among whom were Carlos Saco del Valle, Ignacio Massaguer, and Blas Echegoyen (pp. 258-259). Music shops-e.g., Bazar Filipino, Bazar Oriental, La Lira Filipina, La Puerta del Sol, and El Progreso - abounded which offered instruments for sale such as pianos, violins, and guitars; repair services; and music tutorials (Chua, 2017, pp. 340-354). In addition, new theatre houses were opened such as Teatro Variedades (1879), Teatro Filipino (ca. 1880), Teatro Zorrilla (1893), and the Manila Grand Opera House (1900). There was also the quick dissemination of information about musical productions through printed daily newspapers such as El Comercio and Diario de Manila. These periodicals are an evidence of the vibrant economy in Manila that was characterised by expanded technological change, advancing industrialisation, and rapid urbanisation. Both the dynamic relations and forces of musical productions in Manila in the late nineteenth century constituted the economic structure of the colony's social and cultural formation, which initiated changes that allowed for increased social mobility among indigena (island-born native or indio) musicians. Manila was then experiencing the heat of local modernity.

As a result, these technological changes (forces of production) heightened the existing relations of production and introduced new ones (such as commodification) as demand for music from the public increased, prompting aficionados, musicians, and other artists to form unions to create a system of institutionalised representation for themselves. Exchanges between the various players of the musical mode of production required matching forces to avoid exploitation, particularly of labour. The growth of musical associations was connected to the general yearning for organised and formal support, primarily from the private sector, for the betterment of musicians' welfare, competency, and opportunities. It was necessary to reconfigure the relations of production for musicians because the capitalist system placed a high premium on the concept of musical labour and performances as commodities to buy and sell (Olmsted, 2002, p. 128).

\section{Musical Patronage in Manila}

Since patronage in the performing arts is costly, it was necessary to establish organisations to be able to produce and sustain operas, zarzuelas, orchestras, bands, and other large musical groups. Howard Becker (2008), in his explanation of the interconnectedness of cultural agents and producers in 'Art Worlds', states that

the costs of contemporary arts organisations - symphonies, operas, repertory theatres, and ballet—are so great no one patron can cover them. As a result, the people who might patronise individual painters or writers collaborate to support these organisations, and the coordination of that collaboration necessitates an elaborate ate paraphernalia of boards and auxiliaries to carry on the required fund raising. Patrons of these major cultural enterprises give enough to maintain a continuous flow of performances and the preparation of new productions (p. 104).

Organisations were formed by the rising culturally supportive elite and middle-class that had capital. The formation of musical associations gave the indigena musician a choice to depend on economic forces other than the church or military, similar to the experience of European musicians in the eighteenth century in which their contracts that constituted a relation of domesticity with their patrons - courts, churches, or town councilswere transformed into one of exchange (Burkholder, et al., 2014, p. 452). Musicians began to work for the 
public who was accountable for bestowing popularity. Thus, a musician who was able to measure and serve the taste of this selective public and exercise a keen business sense, capped with supreme adaptability was the ideal cultural producer in the new system. Taylor (2016) adds "producing in and for a market in large-scale fields of cultural production ... is not the same thing as writing to please a patron in the feudal era" (p. 26). This explains the proliferation of music that catered to popular appeal in the late nineteenth century such as familiar arias from favourite operas and zarzuelas, salon piano music, and orchestral overtures rearranged for bands.

A significant factor in the new relations of production was the emergence of the upper and middle classes who, as consumers, paved the way for the commodification of music. They determined the direction of music's production, distribution, and consumption. Belonging to these social classes were the wealthy aficionados and ilustrados who would soon realise the need to form associations to further the cause of cultural education and advancement in the colony as they themselves were embodiments of the developing modernity.

In Bayly's (2004) study of global transformations in the seventeenth and eighteenth centuries, he mentioned that there was

... something distinctive about the Western urge to create clubs, societies, and meeting places ... commoner and merchant families participated in the creation of a myriad new clubs dedicated to sociability, education, trade, and sport ... The proliferation of associations and societies of self-organisation gave Western societies a considerable staying power and solidity, for both internal cohesion and external aggression. It was rooted in the rapid social mobility created by the expansion of internal production and external commerce in the eighteenth century (pp. 72-74).

Goehr (1992) adds that private societies and musical academies were formed in European cities in the nineteenth century for the "mutual support and action in the cause of art . . . [and] sought to institutionalise ... new interest in music, autonomously conceived and severed from its connections with extra-musical institutions" (pp. 239-241). Goehr (1992) lists the following British societies founded in the early nineteenth century: the Philharmonic Society (1813), Royal Academy of Music (1826), and Society of British Musicians (1834) (p. 241). Many of these musical societies were formed to accommodate their specific objectives such as an earlier society founded in London in 1768 whose purpose was to promote ancient music performance, and the Dresden Singakademie founded in 1807 that took as its objective the performance of neglected classics (Goehr, 1992, p. 245).

In forming musical associations, Manila's upper and middle classes created spaces for social relationships to prosper and advanced their social and cultural goals. They thus jockeyed themselves into position in the otherwise colonial milieu, exercising control over cultural taste and helping solidify their ranks in the social class structure. These associations provided a dependable network of relations and interests outside their business and entrepreneurial environs, thus creating venues for personal development, political advancement, and social mobility. Some members of the upper class singularly patronised private orchestras or bands, taking the management of such as their own entrepreneurial affair. They assumed the responsibility to support the livelihood of the members of their musical groups, most of whom were poor, providing the musicians lodging, food, and other basic needs. In some cases, these individual patrons even supported the musicians' families. They forged fictive kinship that fostered a two-way interpersonal compadrazgo relations between the padrino (wealthy patron) and the local musicians (Mojares, 1985, p. 96). The vertical reciprocity of this compadrazgo relations allowed for the social integration of the musicians from the lower class through their membership in associations while at the same time, the patrons benefited from the services and inscribed allegiance of the local musicians. Patrons - criollos and mestizos - from the upper classes who nurtured anticolonial nationalist sentiments used these associations to advance and protect the welfare of the musical laboured, despite it being considered as a threat to the core structure of capitalism (Murthy, 2015, p. 139-41).

This unique compadrazgo devotion is displayed in the relation of Francisco Roxas, one of the wealthiest men in the colony in the late nineteenth century and a generous patron to many musical and artistic productions, and José Estella, a criollo composer who frequently provided music in Roxas' social events. Roxas was charged with sedition and accused for rebellion against Spain in August 1896. On the night of his arrest, the criollo musician, José Estella, rode with him in the carriage that brought Roxas to the prison cell (Roxas, 1970, p. 121). Roxas would eventually be executed in January 1897, a few days after José Rizal was martyred in December 
1896. This shows that while music productions flourished, the overarching capitalist infrastructure was not exempted from the complexities of the unfurling revolutionary atmosphere.

\section{Advancement of Music Education and Promotion of the Arts}

Foremost in the objectives of these associations was to foster the progress of musical education in the Philippines. By the last quarter of the nineteenth century, there has been a clamour to lay the foundations for a conservatory of music in Manila, evidenced by the reviews of music performances in the capital and its suburbs, Quiapo, San Miguel, and Pandacan (Santos Jr., 2018, pp. 12-18). In 1890, José Rizal also wrote about the need to establish such an institution in Manila (Irving, 2010, p. 119). The only formal institution whose sole focus was music was the Colegio de Niños Tiples de la Santa Iglesia Catedral which centred its training on the musical needs of the church. In the absence of a formal institution, these associations catered informally to the demand for musical learning through the orchestras and bands they maintained.

Musical associations and the groups they maintained, through their institutionalisation, resemble the attempt to gain more control in the process of putting order or structure to musical production. Attali (1985), in his extensive examination of the political economy of music, insinuated that musicians who came from the common people need to undergo an efficient process of normalisation to afford them to become spokesmen for a harmonic order (p. 62). This process of normalisation was to turn musicians into producers of that same order and aesthetics, which were designated as the functions of conservatories (Attali, 1985, p. 63). In the absence of music conservatories in Manila in the late nineteenth century, this task of putting order and the eventual control over musicians' production was assumed by the associations whose orchestras became the practical training ground for such.

Liceo Artistico-Literario's formation was the first serious attempt of artists and writers in Manila to form a consortium to "propagate all legitimate manifestations of literature and art" (Retana, 1910, pp. 149-157). It was envisioned to be a "center of instruction and recreation ... founded within the domains of artistic-literary sphere" (El Comercio, 11 December 1877). According to Bañas (1924), the founders of the Liceo ArtísticoLiterario "had in mind to convert it afterwards into a Conservatory of Music and Declamation" (p. 18). The realisation of this goal would eventually be achieved in 1916 upon the establishment of the University of the Philippines Conservatory of Music under Act 2623 of the Philippine Assembly, passed on 4 September of that year, under the proposal sponsored by Senator Joaquin Luna.

To fulfil its mission "to spread the love of the beautiful, and to instruct and honour men who for their worth have achieved a distinguished position in literature or in the arts" (El Comercio, 18 February 1879), the Liceo had programmed different functions that were held weekly, monthly, and occasionally-veladas, concerts, baile1 de trajes (costume balls), and artistic competitions. These functions provided the necessary space for convergence, answering the clamour by the El Comercio critic who reiterated that "for its kind, there should be a meeting place of the good society in any population of any importance, more so in Manila where neither abound, nor are frequent [artistic, literary, and educational gatherings] or public performances" (El Comercio, 3 June 1879).

Aside from the weekly veladas held at the halls of the Liceo, the association also presented concerts at the Teatro de Variedades which opened in early 1879 to replace the Teatro Principe Alfonso which burned down in 1878 (Laconico-Buenaventura, 1979, p. 22). This was administered by the dramatic section of the association that planned and staged zarzuelas, comedies, operas, and orchestral concerts. In May 1879, the Liceo presented the comedy Los Pavos Reales, arranged in Spanish from the French original by José Nunez de Lara y Tavira, and the dramatic work Mas Vale Maña que Fuerza by Manuel Tamayo y Baus (El Comercio, 21 May 1879). In June and July of the same year, it staged the following works: Las dos joyas de la Casa; Los dos ciegos; Los dos hijos; and Dos truchas en seco, also at the Teatro de Variedades (El Comercio, 27 June 1879). Its 14 August 1879 offering combined instrumental music and dramatic works. The following is the entire program for that evening's concert:

$1 .^{\circ}$ Symphony [no specific title], played by the orchestra; $2 .^{\circ}$ Trapisondas por bondad, a comedy in one act, arranged from the French original by A.M. Segovia; $3 .{ }^{\circ}$ First "Romanza Without Words" for violin, harmonium, and piano by Felix Mendelssohn; 4. "Romanza" for baritone by Donizetti; 5. "Meditación" for violin, 
violoncello, harmonium, and piano by A. Durant; $6^{\circ}$ Aria for bass from L'Ombra de la croce by Barri; $7 .^{\circ}$ L'ingenue gavotte by L'Arditti, quintet arranged by Luis Vicente Arche; and $8 .^{\circ}$ El Payo de la carta, a funny sainete by Ramón de la Cruz (El Comercio, 12 August 1879).

\section{Regulation of Musical Practice: Organisational Structures}

The membership of these associations came from all segments of the colonial population, with the preponderance of the cultural elite, which was made up of musicians and aficionados from the upper and middle classes. Naturally, this circle was small and it was foreseeable that members of one association could take part in other organisations, providing a web of institutionalised consortia of cultural agents and players, linked to the larger socio-political and economic forces in the network of cultural production. The associations served as venues for expanding social networks, both for the aficionados and musicians. Among the prominent artists and aficionados who became the prime movers of music associations include Francisco Roxas, Manuel Garrido, Pedro Gruet, Carlos Saco del Valle, Marcelo Adonay, Blas Echegoyen, Manuel Walls, Oscar Camps, Fr. Cipriano Gonzales, Ignacio Massaguer, Ramon Valdes, Bonifacio Arevalo, Antonio Garcia, and Bonifacio Abdon. They sat as founding board members or music directors of these musical associations. A few of these were also inclined to the political persuasions of the time, particularly towards the growing anti-colonial nationalism that would culminate in the 1896 revolution. Francisco Roxas and Bonifacio Arevalo were two of the prominent wealthy aficionados who served as officers of La Liga Filipina ${ }^{2}$, a propaganda movement primarily composed of ilustrados and members of the upper and middle class, founded by José Rizal in 1892 (Manuel, 1955, pp. 61-64; 1970, pp. 204-205).

The membership of Liceo Artístico-Literario was composed of recognised artists and writers, "which included the men of greatest culture in the country" (Retana, 1910, p. 149). They were individuals who were distinguished as being "a musician, or a man of letters, or a fan of the dramatist, or a connoisseur of any of the fine arts" (p. 151). Thus, the composition of the association was made up of both the producers and consumers of artistic and literary arts, primarily from the insulares and the ilustrados of late nineteenth-century Philippines. Their number was "quite considerable and not everyone [was] given the chance to participate in the pleasant meetings in which they share[d] the task of instructing and delighting the participants with the immortal works of the great musicians, writers, and artists" (p. 150). The Liceo Artístico-Literario hosted competitions that encouraged the creation of a variety of artistic works - musical compositions, poetry, plays, and other literary writings - from the resident artists of the colony. According to Retana (1910), the association's

main men were Spanish, [but it exercised] a marked inclination towards the Filipinos; so marked that they exclusively celebrate[d] competitions in which [locally domiciled artists like] Icaza, Romasanta, Aristegui, Rosario y Sales, the Aguirres, Rizal, etc. were awarded, sometimes in opposition to the peninsula's. It is also worth noting that it did not have the support of religious corporations, not even Dominicans, who, because they were in charge of higher education, should have highlighted their most sapient individuals ... (p. 153).

In contrast to the association which was composed mostly of colonial aristocrats, and ilustrados and aficionados from the burgeoning middle class, the second type of association is composed exclusively of musicians, both amateur and professional, from the middle and lower classes whose primary intent in converging was the regulation and professionalisation of their labour. The Sociedad Concierto Unión Artístico Musical was established more as a guild to answer "the demand for professional musicians in commercial entertainment in Manila" (Yamomo, 2017, p. 61).

The regulation of the Unión was patterned after the Sociedad de conciertos in Madrid and it was envisioned to help initiate noticeable advancement in Filipino music (El Comercio, 13 June 1885). The orchestra was to be composed of 100 profesores (musicians) and was to hold regular concerts in the months of November, December, and January annually (El Comercio, 13 June 1885). This huge group of musicians was expected to answer the demand for orchestral needs or any act or event that required the assistance of orchestras as it was part of the association's objectives to discourage the proliferation of small orchestras in Manila whose music making was extremely limited from a musical point of view (El Comercio, 13 June 1885). The artistic director was entitled to six times the salary of the 1st class musicians, thus receiving 18 pesos monthly (Articulo 16). Each musician, upon acceptance to the association was required to pay five pesos as entrance fee, and 
subsequently paying four reales fuertes (Spanish monetary system) monthly contribution (Articulo 18). It is to be noted that the musicians were not employed full time by the union. It was a common practice for musicians to be members of different orchestras and bands (Bañas, 1924, p. 14).

The members of the union were required to execute their individual parts in the music production which made them productive workers. As mentioned earlier, they were the image of programmed labour in society where each of them produced only a part of the whole (Attali, 1985, p. 66). The union's Reglamento tediously defined the organisation of the group with an elected board that acted as the brain and leader of the musicians (Articulo 25-34). It also provided a scheduled annual concert season where the society's funds were projected to come from, and the manner of handling the funds (Articulo 35-42). The normalisation process mentioned earlier is evident in the articles of Capitulo IX-disposiciones generales (general dispositions) discussing the ethics, proper decorum, and the corresponding penalties for failure to abide by the union's regulations.

As one among many musical organisations, the Unión Artístico-Musical indicates the configuration of musical and artistic groups that parallels the machineries of the bigger economic structures in the society. Aimed at specific objectives such as the improvement of the moral and material situations of music teachers and orchestras, and the general progress and development of the arts that existed in Manila in the late nineteenth century (Articulo 1), the union was actually empowering Filipino musicians who were given control of their own labour and means of production. The capitalist aim of the union was probably the accumulation of more social funds through successful income-generating concerts, tying the many activities of the association with the middle class' growing need for affirmation of their emerging power position in late nineteenth century Manila's economic and social formation.

Similarly, the Sociedad Musical Filipina de Santa Cecilia classified its members as: De Numero, Auxiliares, Protectores, Corresponsales, and Honourarios (Articulo 6-18). De numero are music teachers, musical writers and amateurs who, without practicing the profession, cultivate the art and are in the position of being able to lend to society their musical cooperation, paying a monthly contribution of $\$ 0.75$. Auxiliares are those who live from the exercise of musical art, lack the resources to contribute to the ends of society in another way than with their artistic cooperation, remunerated as those who are not considered as learned. In addition to gratuitous assistance to the acts of the society, they will participate in the compensation that divides the same between them and of the aid and relief benefits, but they will not be able to exert any charge in the governing and section boards nor in the commissions. Protectores are lovers of music who do not lend their artistic skill to the society and wish, nevertheless to be part of it, and are required to contribute One Peso monthly. Corresponsales are music teachers and musical writers who reside outside Manila or the archipelago and whose name lends honour to the association, from whom some annual work are requested. Honourarios are those who are considered great geniuses, composers or musical literati, both national and foreign, who are said to accept the respectful tribute of admiration that society offers them by means of his appointment.

\section{New Market and the Commodification of Musical Labour}

Prior to the formation of musical associations, Spain's legacy in musical transmission - the Catholic Church and the Spanish Military Regiments - had already established before the late nineteenth century a patronage system that was centred on music's ritual functions in solemnising church occasions, celebrating religious festivals, carrying out official military band functions, and thus reiterating the ceremonial character of music in a colonial society. Before the advent of capitalism in the colony, musicians worked mainly for the Churchemployed as cantores or organists, and the Spanish military-appointed as band members. These positions were competitive in nature and the Church or the military employed those who successfully passed the rigorous process of musical examinations. Musicians who were able to rise in the structural hierarchy of these formal institutions were able to elevate their social status through being assigned as maestro de capilla of a church or as bandmaster of any of the seven regimental bands. ${ }^{3}$ These bands also served unofficial civic functions by performing at weekly concerts in town plazas - the most popular of which were the two adjacent parks of Luneta and Malecon in Manila, as well as providing music to the balls and dances of Manila's elite. ${ }^{4}$ Perhaps the most visible civic function of bands and orchestras was playing for the fiesta celebrations of each Christianised town of the colony. Fiestas were considered as the socio-cultural high points of the year-helping legitimise and glorify the Spanish colonial (religious) presence in the Islands - and they were celebrated with 
much pomp highlighted by awe-inspiring spectacles featuring entertainment music from the popular theatre and zarzuela artists, parades, banquets, fireworks, cockfights, fairs, sporting competitions, trade displays, and many more (Wendt, 1998, p. 5). The ubiquity of music performances from the bands and orchestras displays the simultaneity of their functions, fulfilling both the Church and military-patronised ritual music-making and the bourgeoning publicly-patronised entertainment 'concert' music. This crossing-over from one function to another shows how musicians manoeuvred from different patronage systems, adopting to the demands of the new capitalist market.

In both colonial institutions, musical labour was recognised and remunerated, albeit differently. The Church exempted its musicians from paying tribute, afforded them freedom of movement and subsidised travel, paid an annual rice subsidy, gave them access to expensive musical commodities and technology, and provided opportunities for them to mingle with ecclesiastical authorities (Irving, 2011, pp. 119-121). The military, on the other hand, applied a standardised salary scheme for its band members, providing "the first professional music employment for the lowest class in the colonial society" (Yamomo, 2017, p. 68). Musicians were accorded a certain status by the colonial population because one needed to possess a high level of musical aptitude - a cultural capital - and must have passed a rigid competition in order to be employed by the Church or the Spanish regiments. In addition, musicians employed in the late nineteenth century kept an elevated social position that occupied the same rank as lawyers and doctors, and enjoyed patronage from the two major colonial institutions. As such, indigena musicians who derived their principal income - in money and other remuneration formsfrom their employment with these two institutions, who at the same time experienced significant changes in their social positions may be regarded more as 'specialists' (Brown, 2007, pp. 3-4).

When the effects of capitalism were beginning to be felt by the general colonial population in the late nineteenth century, a new mode of musical production ensued which veered away from the sacrificial function of music in the old, feudal Catholic Church. The Catholic Church hierarchy in the Islands was known for enforcing a repressive governance led by a central state bureaucracy that demanded forced labour without remuneration among the indigenas (Jackson, 2016, p. 131). Capitalism also diminished the representation of the undisputed pre-eminence of the Spanish colonial government through the military as new alternative musical productions became available. There was a transition from music that was heard in churches and public promenades which were financed by these institutions, into music that was heard by people who paid admission charges, in the form of money, to theatres and status-balancing private-made-public salons of the rich.

A look at the regulations of the Sociedad Concierto Unión Artístico Musical reveals how its members were remunerated for musical services rendered. Excluding the conductor, of its roster of 99 musicians, 15 were classified as first class musicians who received a monthly share in the society utilities of three pesos each, 30 as second class who received two pesos and a half, another 30 as third class who received two pesos, and 24 as 4th class who received one peso and a half (Articulo 15). The top position of the orchestra was the artistic director who was in charge of the preparation of the program and was remunerated with sixfold the amount received by first class musicians-eighteen pesos (Articulo 18).

\section{Acceleration of Modernity: Protecting Musicians' Welfare and Compadrazgo Relations}

A few of these associations maintained secondary objectives such as Sociedad Musical Filipino de Santa Cecilia which focused on the improvement of the welfare of its partners, with special emphasis on those who needed financial help. In Article 3 of the statutes, a relief fund gathered through voluntary donations was to be instituted which composed $12 \%$ of all income and to be used to improve the financial status of some members of the association. This specific regulation exhibits the association's multi-class membership and the intention to improve the financial position of members belonging to the lower social class. The association acted as an agent for social improvement through the provision of funds generated from donations and other sources of revenues to allow them to increase social mobility through an improved economic position, and emphasising mutual personal cooperation and social relations among its members.

Within the Sociedad, the upper class padrinos (and madrinas) were accorded a considerable "degree of social legitimacy" (Mojares, 1985, p. 97). Outside of the Sociedad, they were acknowledged as the association's leaders who represented it in business transactions and other negotiations that forged social relations with other players in the network of Manila's expanding capitalist society. This even extended to 
transactions outside of the colonial capital as demand for Manila musicians brought "band-masters, and later managers [of overseas bands], . . . to Manila and coordinated their recruitment of musicians with referrals through ... music societies such as the Sociedad Musical Filipina de Santa Cecilia, through which musicians in the Sta. Cecilia Band in Singapore were enlisted" (Yamomo, 2017, p. 29).

Sociedad Musical Filipina de Santa Cecilia represents an almost utopian version of capitalism where the dominant wealthy class reproduces capital through the production and distribution of music in its various commoditised forms, remunerating musical labour in a structured manner and generating as much profit as possible in order to operate more lucratively, and maintain a benefit fund which addresses the economic welfare of its disadvantaged members. This is not a common scenario in a capitalist society because by the very nature of the capitalist economic system, the gap between the rich and poor tends to widen as those who own capital have more means and opportunities for its reproduction while those who have none naturally are not able to reproduce, except to earn wages from their labour. Bayly (2004) asserts that

the vast disparities in world living standards which were apparent by the end of the nineteenth century may have been more about external regimes of money and military power than about relative technical progress. The industrial life-style was as much about the desire of the wealthy to control the poor as about economic efficiency in its own right (p. 183).

The desire to control opens up "the possibility of exploitation and the diverse class structures that might support it, where the ones who produce a surplus do not appropriate it" (Irizarry, 2013, p. 42). The poor have no ownership of the means of production, thus "they have to sell their labour power in exchange for a wage to be able to eventually acquire their means of subsistence" (p. 12). On the other hand, Murthy posits through her elaboration of Chakrabarty's concept of History 2, the utopian goal of advanced capitalism is for workers to no longer need to labour extensively to produce wealth, albeit the challenge lies in the creation of a society in which wage is not the dominant economic force for existence (Murthy, 2015, p. 151).

The leadership of Sociedad Musical Filipina de Santa Cecilia was made up of private wealthy patrons who forged relations with others in the field of music production. The Board of Directors managed a mixedclass cultural organisation that helped indigena musicians coming from impoverished economic background. These private individual patrons "afford[ed] to be the models of enlightened generosity" (Becker, 2008, p. 104). They were mostly protectores who funded the formation of the society in order to have easier access to and control over musical productions, particularly those that required the costly services of an orchestra or a band. Reiterating what Becker has stated, such costs

are so great no one patron can cover them ... Patrons of these major cultural enterprises give enough to maintain a continuous flow of performances and the preparation of new productions. They get no collectable objects to display as evidence of their taste and seriousness, but their names appear in programs, and they sometimes get credit for financing a new production .... and thus receive a certain amount of status honour (p. 104).

The protectores thus, gave indigena musicians from the lower class the access to the exclusive field of elite music making. These patrons made it possible for the relations of production to expand, bridging the gap among classes and allowing for a more dynamic society in which social mobility was the outcome.

As a form of exchange, the indigena musicians, using their acquired technical facility, were paid for their labour that got embodied in musical performances enjoyed by many. These became in turn sources of status and honour among those who supported the arts. From their end, they created opportunities for the wealthy aficionados to assert their already attained cultural position by promoting the simulacra of social ordering, programmed labour, harmonic economy, and the essential figure of power through the orchestra that they funded (Attali, 1985, pp. 65-66).

Sociedad Musical Filipina de Santa Cecilia was the lone musical association included in this larger social field. Although seemingly secure, the Sociedad Musical de Santa Cecilia provided a small fissure in the demarcations between social classes because through the very nature of a wide-ranged class membership of the association, the predominantly upper class directors opened the space within the organisation that allowed for the mobile movement of its subsidised auxiliary members who were mostly indigena musicians, giving them a glimpse of high society relations, interests, and way of life. In a way, they were acting as the indigena musicians' 
padrino, a social capital, in the vertical reciprocal fictive kinship links that are inscribed in Christian interpersonal compadrazgo relations (Mojares, 1985, pp. 96-97). The vertical aspect of this social relation is two way. It helped the indigena musicians, as clients, to be socially integrated in the association, but their patrons depended on them as well for the Sociedad's functions.

A strong motivation for the upper class socios de numero and protectores why they endeavoured to bridge the gap between the classes in their association could have been the benefit they derived from the services offered by their 'dependents,' and the probable acknowledgement of a moral obligation stemming from the compadrazgo system endorsed by the Catholic Church. As patrons, it was necessary to invest in the creation of "goodwill among followers and dependents for the purpose of assuring cooperation and subservience" (Mojares, 1985, p. 99). Mojares adds that "moral notions increasingly become prominent as a motive force ... [that translate into tradition, which may be] created out of an interplay of self-interested acts and choices, but it is in the end held together and sustained by shared notions of a common moral order" (p. 100).

\section{Conclusion}

Patronage of music in Manila in the late nineteenth and early twentieth centuries represented the simultaneous presences of continuing feudal and new capitalist systems of remunerating musical labour and managing music productions. While the new dominant economic system focused on the commodification of music, its complex machinations benefited mostly the aficionados, impresarios, and other music practitioners from the upper echelons of the colonial society. In short, only those who have been educated on the limitless advantages of effective business management and entrepreneurship grasped the essence of converting music productions into a huge source of the most potent tool of capitalist exchange system-money. This important resource oiled the various machineries of the musical mode of production including the complex web of the relations of production as they mastered the new forces of production in the modernising colonial capital.

Most of the indigena musicians, however, were only beginning to accumulate cultural capital upon the onset of capitalism in the colony. This limited their capacity to reproduce their acquired capital because they lacked the monetary inducement necessary to multiply production. Thus, a need to organise themselves together to pool their meagre financial resources became an imperative action, forming musical associations to lend strength towards the realisation of their goals and to have a stronger representative voice that can compete with the established institutions already at work in the capitalist society. Propitiously, the upper and the bourgeoning middle classes of the colonial capital needed social symbols and actual representations of their new status and acquired taste that marked their possession of cultural capital. The closest symbol that encompassed everything they wished to project was found in the orchestra (and the band), with all its representation of social ordering, division of labour, and the image of power in the character of the conductor. Since it was too costly to finance an orchestra, the wealthy members of the upper and upper middle classes of Manila formed musical associations in order to have easy access to an orchestra. A few of these founded by aficionados provided all the possible privileges - the most basic of which was exemption in paying the normal monthly fee - to orchestral musicians in order to lure the indigena musicians to join their associations, thus, establishing compadrazgo relations that emphasised the paternalistic patron-client connection. In most cases, this compadrazgo relation functioned vertically where patrons assumed the traditional master position and the musicians became their dependents, particularly in the practice of their art.

More than these associations' recognised aims upon their foundation, they provided institutionalised avenues for musicians and aficionados to establish social networks that allowed them more possibilities for mobility in the colonial system. Through joining different organisations, these cultural agents expanded the workings of socio-political and economic forces during the Spanish and American colonial periods. Memberships in these associations became symbols of prestige, the security of which were supported by the strength of institutionalisation, and allowed the Filipino musicians to involve themselves in various relations of cultural production.

\section{Endnotes}


${ }^{1}$ The Philippine revolution began with concerns to bring liberal and progressive reforms to the Islands, which later turned into a complicated struggle for the emancipation from Spanish colonial grip. This was aggravated by the 1872 execution of the three martyr priests - Mariano Gomez, José Burgos, and Jacinto Zamora — and the worsening denigration of the Filipino race by the Spaniards (Schumacher, 1981, p. 36).

${ }^{2}$ La Liga Filipina was among the three propaganda movement organisations, the two others were the Cuerpo and the Katipunan, that advanced nationalist objectives in the late nineteenth. It was founded by José Rizal and inaugurated on 3 July 1892. The Liga represented the aristocrats of Philippine colonial society, which explains the involvement of many of the wealthy musical patrons of the period.

${ }^{3}$ The known regiments stationed in the islands were Regiment Nos. 5, 7, 8, 71, 72, 73 and 74 (Rubio, 1959, p.12). These bands were routinely assigned to Manila, Cavite, Cebu, Cotabato, Iligan, Jolo, and Zamboanga (Tan, 2014, p. 66).

${ }^{4}$ William Summers' digital collection of nineteenth century Manila newspapers covers more than twenty years of archival work, and this extensive research will appear in a forthcoming publication entitled Repairing the fractured mirror: A chronicle and source book devoted to the performing arts in Manila, 1848-1898.

\section{References}

Anonymous. (1877, December 11). Liceo artistica. El Comercio.

Anonymous. (1879, February 18). Velada en honour á Bécquer. El Comercio.

Anonymous. (1879, June 3). Velada. El Comercio.

Anonymous. (1879, May 21). Liceo. El Comercio.

Anonymous. (1879, June 27). Función dramática. El Comercio.

Anonymous. (1879, August 12). Liceo. El Comercio.

Anonymous. (1885, June 13). Sociedad de Conciertos Unión Artístico Musical. El Comercio.

Attali, J. (1985). Noise: The political economy of music. (B. Massumi, Trans.). Minneapolis and London: University of Minnesota Press.

Bañas, R. C. (1924). The music and theater of the Filipino people. Manila: Oriental Printing.

Bayly, C. A. (2004). The birth of the modern world: 1780-1914. Oxford: Blackwell Publishing.

Becker, H. S. (2008). Art worlds: 25th anniversary edition, updated and expanded. Berkeley, Los Angeles, and London: University of California Press.

Bourdieu, P. (1986). The forms of capital. In J. G. Richardson (Ed.) Handbook of theory and research for the sociology of education (pp. 241-58). New York, NY: Greenwood Press.

Brown, K. B. (2007). The social liminality of musicians: Case studies from Mughal India and beyond. Twentieth-century music, 3 (1), 13-49.

Buenconsejo, J. S., (Ed.) (2017). Philippine modernities: Music, performing arts, and language, 1880-1941. Quezon City: The University of the Philippines Press.

Burkholder, J. P., Grout, D. J., \& Palisca C. V. (2014). A history of western music (9th ed.). New York, NY and London: W.W. Norton \& Company.

Chua, M. A. I. (2017). Composing the Filipino: Music transculturation and hybridity in nineteenth century urban colonial Manila (1858-1898). (Unpublished doctoral dissertation). University of the Philippines.

Chua, M. A. I. (2018). Selling the music: Music stores and distribution companies in colonial Manila, 1873-1942. In A.Q.Tan (Ed.) Saysay Himig: A sourcebook on Philippine music history, 1880-1941 (pp. 257-64). Quezon City: The University of the Philippines Press.

Estatutos de la Sociedad Musical Filipina de Santa Cecilia. (1889). Manila: Tipográfico de Ramírez y Compañía.

Goehr, L. (1992). The imaginary museum of musical works: An essay in the philosophy of music. Oxford: Clarendon Press.

Irizarry, I. J. S. (2013). The political economy of cultural production: Essays on music and class (Doctoral Dissertation). Retrieved from http://scholarworks.umass.edu/open_access_dissertations//820.

Irving, D. R. M. (2010). Colonial counterpoint: Music in early modern Manila. New York, NY: Oxford University Press.

Irving, D. R. M. (2011). Employment, enfranchisement and liminality: Ecclesiastical musicians in early modern Manila. In G. Baker and T. Knighton (Eds.) Music and urban society in colonial Latin America (pp. 117-131). Cambridge: Cambridge University Press.

Jackson, J.F. (2016). "A military necessity which must be pressed": The U.S. Army and forced road labour in the early American colonial Philippines. In M.Van der Linden and M.R.Garcia (Eds.) On Coerced labour : Work and compulsion after chattel slavery (pp. 127-58). Boston: Brill.

Laconico-Buenaventura, C. (1979). The theaters of Manila: 1846-1896. Philippine Studies 27 (no. 1), 5-37. 
Maceda, J. M. (1973). Music in the Philippines in the nineteenth century. In Robert Günther (Ed.) Musikkulturen Asiens, Afrikans und Ozeaniens im 19.Jahrhundert (pp. 215-232). Regensburg: G. Bosse.

Manuel, E. A. (1955). Dictionary of Philippine biography (Volume 1). Quezon City: Filipiniana Publications.

Manuel, E. A. (1970). Dictionary of Philippine biography (Volume 2). Quezon City: Filipiniana Publications.

Mojares, R. B. (1985). Theater in society, society in theater: Social history of a Cebuano village, 1840-1940. Quezon City: Ateneo de Manila University Press.

Mojares, R. B. (2006). Brains of the nation. Quezon City: Ateneo de Manila University Press.

Murthy, V. (2015). Looking for resistance in all the wrong places? Chibber, Chakrabarty, and a tale of two histories. Critical Historical Studies vol. 2 (no. 1, Spring), 113-53.

Olmsted, A. A. (2002). The capitalization of musical production: The conceptual and spatial development of London's public concerts, 1660-1750. In R. Qureshi (Ed.) Music and Marx: Ideas, practice, politics (pp. 106-38). New York, NY: Routledge.

Qureshi, R. B. (2002). Mode of production and musical production: Is Hindustani music feudal? In R. Qureshi (Ed.) Music and Marx: Ideas, practice, politics (pp. 81-105). New York, NY: Routledge.

Reglamento de la Sociedad de Conciertos Unión Artístico Musical, aprobado por el Gobierno Superior de las Islas en 16 de Mayo de 1885. (1885). Manila: Est. Tipo-Litográfico de M. Perez, Hijo.

Retana, W. E. (1910). Del Teatro en Filipinas, capitulo XVII. Nuestro Tiempo: Ciencias y artes-politica y hacienda año X 137, 149-157.

Roxas, F. M. (1970). The world of Felix Roxas. Manila: Filipiniana Book Guild.

Rubio, H. (1959). Development of the brass band in the Philippines. Philippine Music Festival.

Santos Jr., B. (2018). Proposals for a conservatory of music, 1870s-1890s. In Tan, A. Q. (Ed.) Saysay himig: A sourcebook on Philippine music history, 1880-1941 (pp. 12-19). Quezon City: University of the Philippines Press.

Schumacher, J. N., SJ. (1981). Revolutionary clergy: The Filipino clergy and the nationalist movement, $1850-1903$. Quezon City: Ateneo de Manila University Press.

Tan, A. Q. (2007). Evolving Filipino music and culture in the life and works of Don Lorenzo Ilustre of Ibaan, Batangas. (Unpublished Master's Thesis). University of the Philippines.

Tan, A. Q. (2014). Reproduction of cultural and social capital in nineteenth century Spanish regimental bands of the Philippines. Humanities Diliman, 11 (2), 61-89.

Tan, A. Q. (2018). Music, labour, and capitalism in Manila's transforming colonial society in the late nineteenth century. (Unpublished doctoral dissertation). University of the Philippines.

Taylor, T. (2016). Music and capitalism: A history of the present. Chicago and London: The University of Chicago Press.

Wendt, R. (1998). Philippine fiesta and colonial culture. Philippine Studies, 46 (1), 3-23.

Yamomo, M. (2017). Global currents, musical streams: European opera in colonial Southeast Asia. Nineteenth Century Theatre and Film, 44 (1), 54-74.

\section{Biography}

Arwin Q. Tan is assistant professor of Musicology at the University of the Philippines College of Music in Diliman, Quezon City. He is the editor of 'Saysay Himig: A sourcebook on Philippine music history, 1880-1941', and curator of its accompanying 3-CD recordings 'Saysay Himig: An anthology of transcultural Filipino music, 1880-1941'. He was consultant and contributor to the second edition of the 'Music Volume (VII)' of the 'Cultural Center of the Philippines Encyclopedia of Philippine Arts.' He has written articles and reviews for the 'Humanities Diliman', 'Musika Jornal', 'Saliksik e-Journal', 'Perspectives in the Arts and Humanities' and 'Asian Studies'. Tan also performs as conductor of the four-time, Ani ng Dangal awardee, Novo Concertante Manila, currently ranked 3rd in the top 1000 mixed choirs of the world by 'Interkultur', Germany. He has been accorded the 'International Publication Award' in 2015 by the University ard for the period 2013-2015, and UP Artist II Award for the period 2016-2018. 